\title{
COVID-19 and Chronic Viral Liver Diseases
}

\author{
Maged Tharwat Elghannam*, Motaz Hasan Hassanien, Yosry Abdelrahman, \\ Gamalaldin Mohammed ALattar, Emad Abdelwahab Turky, Ahmed Aly EL Ray, \\ Mohammed Darwish EL Talkawy
}

Hepatogastroenterology Department, Theodor Bilharz Research Institute, EL Warak, Giza, Egypt

Email: *magedelghannam@hotmail.com

How to cite this paper: Elghannam, M.T., Hassanien, M.H., Abdelrahman, Y., ALattar, G.M., Turky, E.A., EL Ray, A.A. and EL Talkawy, M.D. (2021) COVID-19 and Chronic Viral Liver Diseases. Journal of Biosciences and Medicines, 9, 138-146.

https://doi.org/10.4236/jbm.2021.99012

Received: August 19, 2021

Accepted: September 15, 2021

Published: September 18, 2021

Copyright (C) 2021 by author(s) and Scientific Research Publishing Inc. This work is licensed under the Creative Commons Attribution-NonCommercial International License (CC BY-NC 4.0). http://creativecommons.org/licenses/by-nc/4.0/

\begin{abstract}
Coronavirus causes an outbreak of viral pneumonia that spread throughout the world. Liver injury is becoming more widely recognized as a component of the clinical picture of COVID-19 infection. We aimed to review this relation in a concise way. This review article includes a large number of patients from both western and eastern countries with no clear difference of liver affection. The more severe and frequent liver injury, the more severe COVID-19 infection. Up to half of patients developed hepatitis with serum ALT elevation. Both hepatocellular and/or ductular injury were observed as evidenced by alkaline phosphatase elevation. Increase incidence of morbidity and mortality had been recorded in patients with CLD. Cirrhosis mortality extended in line with the Child-Turcotte-Pugh class. The incidence of ACLF in CLD patients with COVID 19 is not clear. There are no significant associations with the etiology of liver disease and death in cirrhosis. COVID-19 hinders HCV elimination by 2030. Patients should continue their medications if already receiving treatment. Patients with occult or resolved HBV and COVID-19 who are receiving immunosuppressive agents should use antiviral therapy to prevent viral flare-ups.
\end{abstract}

\section{Keywords}

COVID-19, Chronic Liver Disease, Cell Entry, Pathology, Pathogenesis and Pathophysiology, Impact on CLD

\section{Introduction}

A novel coronavirus designated as SARS-CoV-2, broke out in the city of Wuhan, China, at the end of 2019, causing the outbreak of viral pneumonia and spread all over the world [1] [2]; it was named "COVID-19" [3].

Cell Entry: 
Angiotensin-converting enzyme 2 (ACE 2) receptors are used for cell entry [4] [5]. In the liver, ACE 2 is highly expressed in the endothelial layer of smooth blood vessels but not in the sinusoidal endothelium, Kupffer cells, or $\mathrm{T}$ and $\mathrm{B}$ lymphocytes [6]. Chai et al. in 2020 [7] reported more abundance of ACE 2 receptors in cholangiocytes (59.7\%) than hepatocytes (2.6\%).

Pathology:

Macrovesicular steatosis was the most common finding. Mild lobe necroinflammation, portal inflammation and sinusoidal microthrombi were infrequent. PCR of liver tissue was positive in 55\% of patients tested [8].

Pathogenesis and Pathophysiology:

Liver injury is becoming more widely recognized as a component of the clinical picture of COVID-19 infection. Half of the patients infected with severe SARS-CoV-2 showed hepatitis with serum ALT elevation [9] [10]. AST/ALT $\geq$ 1.38 was found to be significantly associated with more severe chest CT findings and poor prognosis [11]. The more severe and frequent liver injury, the more severe COVID-19 infection; those with disease progression had a higher frequency of severe liver injury [12] [13] [14]. FIB-4 had independent and dose-dependent assimilation with negative outcomes. However, in the hospital FIB-4 had a significant prognostic value for poor outcomes in COVID-19 patients [13].

The underlying mechanism of the liver injury is unknown. There is mounting evidence that dysregulated immune responses are linked to disease pathogenesis in COVID-19; cytokine storm, defined by significantly elevated plasma levels of proinflammatory cytokines such as IL- 6 and TNF- $\alpha$, has been linked to severe COVID-19 [12] [13] [14] [15]. Direct cell damage by SARS-CoV-2 is also possible due to the presence of ACE 2 entry receptors in the liver, particularly in bile duct cells [16]. Antibiotics, antivirals, traditional Chinese medicine, and secondary bacterial infection, on the other hand, may cause liver damage in COVID-19 patients [17].

The pharmacologic management of COVID-19 includes liver-specific considerations. Contrary to preclinical studies, Remdesivir is safe and does not affect liver function tests [18]. Beigel et al. [19] reported no aminotransferase elevation in patients receiving remdesivir; Wang et al. came to the same conclusion [20]. In case of patients with advanced liver disease, close follow-up is needed. Tocilizumab use results in minor serum aminotransferase elevations [21]. However, reports of progressive jaundice necessitating Liver Transplantation (LT) have been made. Furthermore, its use has been linked to HBV reactivation, and HBV serology should be part of the pre-treatment workup [22]. The use of corticosteroids in IBD patients has been linked to ICU admission, the need for a ventilator, and/or death [23]. Patients with rheumatic diseases and using glucocorticoids had an increased rate of hospitalization [24]. No need to lower immunosuppression in patients with autoimmune hepatitis or LT recipients, including the use of corticoids if necessary [25]. The use of anticoagulant agents revealed no excess bleeding in cirrhosis-related events and portal vein thrombosis [26]. Anticoagulation may have anti-fibrotic properties [27] and may improve survival in cirr- 
hotic patients [28]. This finding is supported by a multicenter study conducted in Italy [29].

\section{Chronic Liver Disease and Liver Cirrhosis}

Patients with Chronic Liver Disease (CLD) and infected with COVID-19 infection account for less than $1 \%$ of reported cases [30] [31]. Lower liver function reserve is responsible for higher risk of morbidity and mortality in CLD patients. Both hepatocellular and/or ductular injury were observed in patients with or without CLD [32]. Singh and Khan [33] study a group of 2780 patients in the United States. Liver injury was reported in the majority of COVID-19 patients; patients with preexisting liver disease, particularly cirrhotic patients, having a higher risk of hospitalization and mortality. Another study, collected by two international registries in the United Kingdom, included 745 patients from 29 countries, 386 with cirrhosis and 359 without. Higher mortality rate (32\%) in patients with cirrhosis was out of comparison to (8\%) mortality rate in those without. Cirrhosis mortality extended in line with Child-Turcotte-Pugh class: CTP-A 19\%, CTP-B $35 \%$, and CTP-C $51 \%$. Respiratory failure became the main reason of death (71\%). Advanced age and alcoholic liver disease were also risk factors for death. When cirrhotic patients with CTP-B and C were compared to patients without liver disease, there was a significant increase in mortality [34]. Other studies reported comparable rates; in Northern Italy (34\%) [29] and North America (39\%) [35]. The observed mortality rates in cirrhotic patients with COVID-19 (32\%) far exceeded those previously reported in hospitalized cirrhotic patients with cirrhosis in the era preceding COVID-19 (5\% - 8\%) [36] [37]. Alcohol-related Liver Disease (ALD) increases the risk of death by 1.8 times because the patients in this study had more severe underlying liver disease; the proportion of ALD patients without cirrhosis was only $6 \%$ compared to $62 \%$ in those with NAFLD. No significant associations with the etiology of liver disease and death in cirrhosis. In a multi-center, observational cohort study of adult patients with CLD and a laboratory-confirmed diagnosis of COVID-19 conducted across 21 institutions in the United States (US), the overall all-cause mortality was 14\%, with $61.7 \%$ having severe COVID-19. Patients who present with diarrhea or nausea/vomiting were more likely to have severe COVID-19. Alcohol-related Liver Disease (ALD), decompensated cirrhosis, and hepatocellular carcinoma were the liver-specific factors associated with an independent risk of higher overall mortality (HCC). Older age, diabetes, hypertension, chronic obstructive pulmonary disease, and current smoking are additional factors. There are increased risk of severe COVID19 infection in hispanic ethnicity and decompensated cirrhosis [38].

It is not clear if there is an increase in the incidence of ACLF in CLD patients treated with COVID-19. Ji et al. [32] from China reported on a study of 140 consecutive COVID-19 patients with pre-existing CLD, including those with liver cirrhosis, NAFLD, chronic HBV, and chronic HCV infection. None of them had liver decompensation when they were admitted. ACLF was found in only 
one CLD patient. In a case report, IL-6 and serum ferritin levels acutely increased, peaking on the day of death, favoring immune-mediated attacks over direct cytotoxic effects. Another possible cause, hypoxic hepatitis, was reported in $2.5 \%$ of ICU patients [39]. Acute hepatic decompensation occurred in 179 (46\%) of cirrhotic patients, with $21 \%$ having no respiratory symptoms; 89 (50\%) of those with hepatic decompensation had ACLF [34].

\section{Impact}

COVID-19 not only impacts morbidity and mortality but also affects hepatitis elimination, with only 10 years remaining to meet the Global Health Sector Strategy targets by 2030 [40]. No one can anticipate the full impact of postponing hepatitis elimination programs. However, Blach et al. [41] used mathematical models to assess the potential impact of programmatic delays on hepatitis disease burden and mortality. It was found that one-year delay in HCV programs could result in increased HCV morbidity and mortality. Also, a one-year pause in HCV elimination programs could result in 72,300 extra liver-related deaths and 44,800 extra liver cancers worldwide. The majority of excess deaths would occur in the lower middle and upper-income brackets. In Egypt, COVID-19 negatively affects the HCV screening program. All ongoing screening packages such as screening of children, pregnant women, foreigners dwelling in Egypt, and prisoners have been halted in March 2020, and the quantity of MoHP affiliated HCV remedy and cirrhosis follow-up units running regularly decreased by extra than 75\%. In Egypt, access to treatment and care has been impacted. MoHP-sponsored HCV management centers have experienced a 50\% reduction in new patients and monthly visits. Also, there are temporary suspended screening programs (unpublished data provided by Professor Imam Waked H).

\section{Management}

Patients with chronic HCV and chronic HBV should continue treatment if already receiving treatment. In addition to standard of care, use telemedicine/local laboratory testing for follow-up visits. Send follow up prescriptions by mail to patients with CLD and cirrhotic patients. In patients without COVID-19, treatment for HCV and HBV should be initiated according to the guidelines [42] [43]; in patients with COVID-19, treatment for HCV and HBV should be delayed. If there is a flare-up, antiviral therapy should be started on a case-by-case basis. Patients with occult or resolved HBV and COVID-19 who are receiving corticosteroids, tocilizumab, or other immunosuppressive agents should receive antiviral therapy to prevent viral flare-ups. All patients with cirrhosis who become infected with COVID-19 should be admitted as soon as possible and managed in a non-COVID-19 ward. Patients with hepatic decompensation or ACLF should offer a priority for SARS-CoV-2 testing [44]. Naturally, all cirrhotic patients should be immunized against Streptococcus pneumonia and influenza [25]. Also, hepatic patients should offer a priority for COVID-19 vacci- 
nation whenever possible to reduce the incidence of morbidity and mortality.

\section{Conflicts of Interest}

The authors declare no conflicts of interest regarding the publication of this paper.

\section{References}

[1] Wu, J.T., Leung, K. and Leung, G.M. (2020) Nowcasting and Forecasting the Potential Domestic and International Spread of the 2019-nCoV Outbreak Originating in Wuhan, China: A Modelling Study. The Lancet, 395, 689-697. https://doi.org/10.1016/S0140-6736(20)30260-9

[2] Hui, D.S., Hui, D.S., Azhar, E.I., Madani, T.A., Ntoumi, F., et al. (2020) The Continuing 2019-nCoV Epidemic Threat of Novel Coronaviruses to Global Health-The Latest 2019 Novel Coronavirus Outbreak in Wuhan, China. International Journal of Infectious Diseases, 91, 264-266. https://doi.org/10.1016/j.ijid.2020.01.009

[3] Coronaviridae Study Group of the International Committee on Taxonomy of Viruses (2020) The Species Severe Acute Respiratory Syndrome-Related Coronavirus: Classifying 2019-nCoV and Naming It SARS-CoV2. Nature Microbiology, 5, 536-544. https://doi.org/10.1038/s41564-020-0695-Z

[4] Li, W., Moore, M.J., Vasilieva, N., Sui, J., Wong, S.K., Berne, M.A., Somasundaran, M., Sullivan, J., Luzuriaga, K., Greenough, T., Choe, H. and Farzan, M. (2003) Angiotensin-Converting Enzyme 2 Is a Functional Receptor for the SARS Coronavirus. Nature, 426, 450-454. https://doi.org/10.1038/nature02145

[5] Penninger, L., Grant, M. and Sung, J. (2021) The Role of Angiotensin Converting Enzyme 2 in Modulating Gut Microbiota, Intestinal Inflammation, and Coronavirus Infection. Gastroenterol, 160, 39-46. https://doi.org/10.1053/j.gastro.2020.07.067

[6] Jothimani, D., Venugopal, R., Abedin, M.F. Kaliamoorthy, I. and Rela, M. (2020) COVID-19 and the Liver. Journal of Hepatology, 73, 1231. https://doi.org/10.1016/j.jhep.2020.06.006

[7] Chai, X., Hu, L., Zhang, Y., Han, W., Lu, Z., Ke, A., Zhou, J., Shi, G., Fang, N., Fan, J., Cai, J., Fan, J. and Lan, F. (2020) Specific ACE2 Expression in Cholangiocytes May Cause Liver Damage after 2019-nCoV Infection.

[8] Lagana, S.M., Kudose, S., Iuga, A., Lee, M.J., Fazlollahi, L., Remotti, H.E., Del Portillo, A., De Michele, S., de Gonzalez, A., Saqi, A., Khairallah, P., Chong, A.M., Park, H., Uhlemann, A., Lefkowitch, J.H. and Verna, E.C. (2020) Hepatic Pathology in Patients Dying of COVID-19: A Series of 40 Cases Including Clinical, Histologic, and Virologic Data. Modern Pathology, 33, 2147-2155. https://doi.org/10.1038/s41379-020-00649-X

[9] Xu, L., Liu, J., Lu, M., Yang, D. and Zheng, X. (2020) Liver Injury during Highly Pathogenic Human Coronavirus Infections. Liver International, 40, 998-1004. https://doi.org/10.1111/liv.14435

[10] Boettler, T., Newsome, P.N., Mondelli, M.U., Maticic, M., Cordero, E., Cornberg, M. and Berg, T. (2020) Care of Patients with Liver Disease during the COVID-19 Pandemic: EASL-ESCMID Position Paper. JHEP Reports, 2, Article ID: 100113. https://doi.org/10.1016/j.jhepr.2020.100113

[11] Zhou, F., Yu, T., Du, R., Fan, G., Liu, Y., Liu, Z., Xiang, J., Wang, Y., Song, B., Gu, X., Guan, L., Wei, Y., Li, H., Wu, X., Xu, J., Tu, S., Zhang, Y., Chen, H. and Cao, B. (2020) Clinical Course and Risk Factors for Mortality of Adult in Patients with COVID-19 in Wuhan, China: A Retrospective Cohort Study. The Lancet, 395, 1054 
1062. https://doi.org/10.1016/S0140-6736(20)30566-3

[12] Wang, D., Hu, B., Hu, C., Zhu, F., Liu, X., Zhang, J., Wang, B., Xiang, H., Cheng, Z., Xiong, Y., Zhao, Y., Li, Y., Wang, X. and Peng, Z. (2020) Clinical Characteristics of 138 Hospitalized Patients with 2019 Novel Coronavirus-Infected Pneumonia in Wuhan, China. The Journal of the American Medical Association, 23, 1061-1069. https://doi.org/10.1001/jama.2020.1585

[13] Xu, X.W., Wu, X.X., Jiang, X.G., Xu, K.J., Ying, L.J., Ma, C.L., et al. (2020) Clinical Findings in a Group of Patients Infected with the 2019 Novel Coronavirus (SARSCov-2) Outside of Wuhan, China: Retrospective Case Series. British Medical Journal, 368, m606. https://doi.org/10.1136/bmj.m606

[14] Xiang, F., Sun, J., Chen, P., Han, P., Zheng, H., Cai, S. and Kirk, G. (2021) Early Elevation of FIB-4 Liver Fibrosis Score Is Associated with Adverse Outcomes among Patients with COVID-19. Clinical Infectious Diseases, 73, e594-e601. https://doi.org/10.1093/cid/ciaa1710

[15] Cao, X. (2020) COVID-19: Immunopathology and Its Implications for Therapy. Nature Reviews Immunology, 20, 269-270. https://doi.org/10.1038/s41577-020-0308-3

[16] Chai, X., Hu, L., Zhang, Y., Han, W., Lu, Z., Ke, A., Zhou, J., Shi, G., Fang, N., Fan, J., Cai, J., Fan, J. and Lan, F. (2020) Specific ACE2 Expression in Cholangiocytes may Cause Liver Damage after 2019-nCoV Infection. Bio-Rxiv. https://doi.org/10.1101/2020.02.03.931766

[17] Zhang, C., Shi, L. and Wang, F.S. (2020) Liver Injury in COVID-19: Management and Challenges. The Lancet Gastroenterology and Hepatology, 5, 428-430. https://doi.org/10.1016/S2468-1253(20)30057-1

[18] LactMed (2006) Remdesivir. Drugs and Lactation Database. National Library of Medicine (US), Bethesda.

[19] Beigel, J.H., Tomashek, K.M., Dodd, L.E., Mehta, A.K., Zingman, B.S., Kalil, A.C., Hohmann, E., Chu, H., Luetkemeyer, A., Kline, S., de Castilla, D., Finberg, R., Dierberg, K., Tapson, V., Hsieh, L., Patterson, T., Paredes, R., Sweeney, D., Short, W., Touloumi, G., Lye, D., Ohmagari, N., Oh, M., Ruiz-Palacios, G., Benfield, T., Fätkenheuer, G., Kortepeter, M., Atmar, R., Creech, C., Lundgren, J., Babiker, A., Pett, S., Neaton, J., Burgess, T., Bonnett, T., Green, M., Makowski, M., Osinusi, A., Nayak, S. and Lane, H. (2020) Remdesivir for the Treatment of Covid-19 Preliminary Report. The New England Journal of Medicine, 383, 1813-1826.

https://doi.org/10.1056/NEJMoa2007764

[20] Wang, Y., Zhang, D., Du, G., Du, R., Zhao, J., Jin, Y., Fu, S., Gao, L., Cheng, Z., Lu, Q., Hu, Y., Luo, G., Wang, K., Lu, Y., Li, H., Wang, S., Ruan, S., Yang, C., Mei, C., Wang, Y., Ding, D., Wu, F., Tang, X., Ye, X., Ye, Y., Liu, B., Yang, J., Yin, W., Wang, A., Fan, G., Zhou, F., Liu, Z., Gu, X., Xu, J., Shang, L., Zhang, Y., Cao, L., Guo, T., Wan, Y., Qin, H., Jaki, T., Hayden, F., Horby, P., Cao, B. and Wang, C. (2020) Remdesivir in Adults with Severe COVID-19: A Randomised, Double-Blind, Placebo-Controlled, Multicentre Trial. The Lancet, 395, 1569-1578. https://doi.org/10.1016/S0140-6736(20)31022-9

[21] Maini, R.N., Taylor, P.C., Szechinski, J., Pavelka, K., Bröll, J., Balint, G., Emery, P., Raemen, F., Petersen, J., Smolen, J., Thomson, D. and Kishimoto, T. (2006) Double Blind Randomized Controlled Clinical Trial of the Interleukin-6 Receptor Antagonist, Tocilizumab, in European Patients with Rheumatoid Arthritis Who Had an Incomplete Response to Methotrexate. Arthritis \& Rheumatology, 54, 2817-2829. https://doi.org/10.1002/art.22033

[22] Chen, L.F., Mo, Y.Q., Jing, J., Ma, J.D., Zheng, D.H. and Dai, L. (2017) Short-Course Tocilizumab Increases Risk of Hepatitis B Virus Reactivation in Patients with 
Rheumatoid Arthritis: A Prospective Clinical Observation. International Journal of Rheumatic Diseases, 20, 859-869. https://doi.org/10.1111/1756-185X.13010

[23] Brenner, E.J., Ungaro, R.C., Gearry, R.B., Kaplan, G.G., Kissous-Hunt, M., Lewis, J.D., Ng, S.C., Rahier, J., Reinisch, W., Ruemmele, F.M., Steinwurz, F., Underwood, F.E., Zhang, X., Colombel, J. and Kappelman, M.D. (2020) Corticosteroids, But Not TNF Antagonists, Are Associated with Adverse COVID-19 Outcomes in Patients with Inflammatory Bowel Diseases: Results from an International Registry. Gastroenterology, 159, 481-491. https://doi.org/10.1053/j.gastro.2020.05.032

[24] Gianfrancesco, M., Hyrich, K.L., Al-Adely, S., Carmona, L., Danila, M.I., Gossec, L., Izadi, Z., Jacobsohn, L., Katz, P., Lawson-Tovey, S., Mateus, E., Rush, S., Schmajuk, G., Simard, J., Strangfeld, A., Trupin, L., Wysham, K., Bhana, S., Costello, W., Grainger, R., Hausmann, J., Liew, J., Sirotich, E., Sufka, P., Wallace, Z., Yazdany, J., Machado, P. and Robinson, P. (2020) Characteristics Associated with Hospitalisation for COVID-19 in People with Rheumatic Disease: Data from the COVID-19 Global Rheumatology Alliance Physician-Reported Registry. Annals of the Rheumatic Diseases, 79, 859-866. https://doi.org/10.1136/annrheumdis-2020-217871

[25] Boettler, T., Marjot, T., Newsome, P.N., Mondelli, M.U., Maticic, M., Cordero, E., Jalan, R., Moreau, R., Cornberg, M. and Berg, T. (2020) Impact of COVID-19 on the Care of Patients with Liver Disease: EASL-ESCMID Position Paper after 6 Months of the Pandemic. JHEP Reports, 2, Article ID: 100169.

https://doi.org/10.1016/j.jhepr.2020.100169

[26] Loffredo, L., Pastori, D., Farcomeni, A. and Violi, F. (2017) Effects of Anticoagulants in Patients with Cirrhosis and Portal Vein Thrombosis: A Systematic Review and Meta-Analysis. Gastroenterology, 153, 480-487.

https://doi.org/10.1053/j.gastro.2017.04.042

[27] Turco, L., de Raucourt, E., Valla, D.C. and Villa, E. (2019) Anticoagulation in the Cirrhotic Patient. JHEP Reports, 1, 227-239.

https://doi.org/10.1016/j.jhepr.2019.02.006

[28] Villa, E., Cammà, C., Marietta, M., Luongo, M., Critelli, R., Colopi, S., Tata, C., Zecchini, R., Gitto, S., Petta, S., Lei, B., Bernabucci, V., Vukotic, R., De Maria, N., Schepis, F., Karampatou, A., Caporali, C., Simoni, L., Del Buono, M., Zambotto, B., Turola, E., Fornaciari, G., Schianchi, S., Ferrari, A. and Valla, D. (2012) Enoxaparin Prevents Portal Vein Thrombosis and Liver Decompensation in Patients with Advanced Cirrhosis. Gastroenterology, 143, 1253-1260.

https://doi.org/10.1053/j.gastro.2012.07.018

[29] Iavarone, M., D’Ambrosio, R., Soria, A., Triolo, M., Pugliese, N., Del Poggio, P., Perricone, G., Massironi, S., Spinetti, A., Buscarini, E., Viganò, M., Carriero, C., Fagiuoli, S., Aghemo, A., Belli, L., Lucà, M., Pedaci, M., Rimondi, A., Rumi, M., Invernizzi, P., Bonfanti, P. and Lampertico, P. (2020) High Rates of 30-Day Mortality in Patients with Cirrhosis and COVID-19. Journal of Hepatology, 73, 1534. https://doi.org/10.1016/j.jhep.2020.08.001

[30] Team CC-R (2020) Preliminary Estimates of the Prevalence of Selected Underlying Health Conditions among Patients with Coronavirus Disease 2019-United States, February 12-March 28, 2020. Morbidity and Mortality Weekly Report, 69, 382-386. https://doi.org/10.15585/mmwr.mm6913e2

[31] Williamson, E., Walker, A.J., Bhaskaran, K.J., Bacon, S., Bates, C., Morton, C.E., Curtis, H., Mehrkar, A., Evans, D., Inglesby, P., Cockburn, J., McDonald, H., MacKenna, B., Tomlinson, L., Douglas, I., Rentsch, C., Mathur, R., Wong, A., Grieve, R., Harrison, D., Forbes, H., Schultze, A., Croker, R., Parry, J., Hester, F., Harper, S., Perera, R., Evans, S., Smeeth, L. and Goldacre, B. (2020) Open SAFELY: Factors Associated with COVID-19 Death in 17 Million Patients. Nature, 584, 430-436. 
https://doi.org/10.1038/s41586-020-2521-4

[32] Ji, D., Zhang, D., Yang, T., Mu, J., Zhao, P., Xu, J., Li, C., Cheng, G., Wang, Y., Chen, Z., Qin, E. and Lau, G. (2020) Effect of COVID-19 on Patients with Compensated Chronic Liver Diseases. Hepatology International, 14, 701-710.

https://doi.org/10.1007/s12072-020-10058-6

[33] Singh, S. and Khan, A. (2020) Clinical Characteristics and Outcomes of Coronavirus Disease 2019 among Patients with Preexisting Liver Disease in the United States: A Multicenter Research Network Study. Gastroenterology, 159, 768-771. https://doi.org/10.1053/j.gastro.2020.04.064

[34] Marjot, T., Moon, A., Cook, J., Abd-Elsalam, S., Aloman, C., Armstrong, M., Pose, E., Brenner, E.J., Cargill, T., Catana, M., Dhanasekaran, R., Eshraghian, A., GarcíaJuárez, I., Gill, U., Jones, P., Kennedy, J., Marshall, A., Matthews, C., Mells, G., Mercer, C., Perumalswami, P., Avitabile, B., Qi, X., Su, F., Ufere, N., Wong, Y., Zheng, M., Barnes, E., Barritt, A. and Webb, G. (2021) Outcomes Following SARS-CoV-2 Infection in Patients with Chronic Liver Disease: An International Registry Study. Journal of Hepatology, 74, 567-577.

[35] Bajaj, J.S., Garcia-Tsao, G., Biggins, S., Kamath, P.S., Wong, F., McGeorge, S., Shaw, A., Pearson, M., Chew, M., Fagan, A., Rodriguez, R., Worthington, J., Olofson, A., Weir, V., Trisolini, C., Dwyer, S. and Reddy, K. (2021) Comparison of Mortality Risk in Patients with Cirrhosis and COVID-19 Compared with Patients with Cirrhosis Alone and COVID-19 Alone: Multicentre Matched Cohort. Gut, 70, 531-536. https://doi.org/10.1136/gutjnl-2020-322118

[36] Schmidt, M.L., Barritt, A.S., Orman, E. and Hayashi, P.H. (2015) Decreasing Mortality among Patients Hospitalized with Cirrhosis in the United States from 2002 through 2010. Gastroenterology, 148, 967-977. https://doi.org/10.1053/j.gastro.2015.01.032

[37] Kanwal, F., Tansel, A., Kramer, J.R., Feng, H., Asch, S.M. and El-Serag, H.B. (2017) Trends in 30-Day and 1-Year Mortality among Patients Hospitalized with Cirrhosis from 2004 to 2013. American Journal of Gastroenterology, 112, 1287-1297. https://doi.org/10.1038/ajg.2017.175

[38] Kim, D., Adeniji, N., Latt, N., Kumar, S., Bloom, P., Aby, E., Perumalswami, P., Roytman, M., Li, M., Vogel, A., Catana, A., Wegermann, K., Carr, R., Aloman, C., Chen, V., Rabiee, A., Sadowski, B., Nguyen, V., Dunn, W., Chavin, K., Zhou, K., Lizaola-Mayo, B., Moghe, A., Debes, J., Lee, T., Branch, A., Viveiros, K., Chan, W., Chascsa, D., Kwo, P. and Dhanasekaran, R. (2020) Predictors of Outcomes of COVID19 in Patients with Chronic Liver Disease: US Multi-Center Study. Clinical Gastroenterology and Hepatology, 19, 1469-1479.e19.

https://doi.org/10.1016/j.cgh.2020.09.027

[39] Tapper, E.B., Sengupta, N. and Bonder, A. (2015) The Incidence and Outcomes of Ischemic Hepatitis: A Systematic Review with Meta-Analysis. The American Journal of Medicine, 128, 1314-1321. https://doi.org/10.1016/j.amjmed.2015.07.033

[40] WHO (2016) Global Health Sector Strategy on Viral Hepatitis 2016-2021: Towards Ending Viral Hepatitis. World Health Organization, Geneva.

[41] Blach, S., Kondili, L., Aghemo, A., Cai, Z., Dugan, E., Estes, C., Gamkrelidze, I., Ma, S., Pawlotsky, J., Razavi-Shearer, D., Razavi, H., Waked, I., Zeuzem, S. and Craxi, A. (2021) Impact of COVID-19 on Global HCV Elimination Efforts. Journal of Hepatology, 74, 31-36. https://doi.org/10.1016/j.jhep.2020.07.042

[42] Lampertico, P., Agarwal, K., Berg, T., Buti, M., Janssen, H.L.A., Papatheodoridis, G. and Zoulim, F. (2017) EASL 2017 Clinical Practice Guidelines on the Management of Hepatitis B Virus Infection. Journal of Hepatology, 67, 370-398. https://doi.org/10.1016/j.jhep.2017.03.021 
[43] Pawlotsky, J.-M., Negro, F., Aghemo, A., Berenguer, M., Dalgard, O., Dusheiko, G., Marra, F., Puoti, M. and Wedemeyer, H. (2018) EASL Recommendations on Treatment of Hepatitis C 2018. Journal of Hepatology, 69, 461-511.

https://doi.org/10.1016/j.jhep.2018.03.026

[44] Moon, A.M., Webb, G.J., Aloman, C., Armstrong, M.J., Cargill, T., Dhanasekaran, R., Genescà, J., Gill, U., James, T., Jones, P., Marshall, A., Mells, G., Perumalswami, P., Qi, X., Su, F., Ufere, N., Barnes, E., Barritt, A. and Marjot, T. (2020) High Mortality Rates for SARS-CoV-2 Infection in Patients with Preexisting Chronic Liver Disease and Cirrhosis: Preliminary Results from an International Registry. Journal of Hepatology, 73, 705-708. https://doi.org/10.1016/j.jhep.2020.05.013 